\title{
Use of odour bait to catch bank voles
}

\author{
Roman ANDRZEJEWSKI and Edyta OWADOWSKA
}

\begin{abstract}
Andrzejewski R. and Owadowska E. 1994. Use of odour bait to catch bank voles. Acta theriol. 39: 221-225.

The aim of this study was to determine whether bank voles Clethrionomys glareolus (Schreber, 1780) could be trapped by the odour of other individuals as opposed to using food as bait. A line of 100 snap traps was set at 2 meters interval in a forest. Odour bait was prepared of polyurethane foam cubes $\left(1.5 \mathrm{~cm}^{3}\right)$ on which few male and female bank voles were kept in a 2 litre glass jar without food and water (to prevent the transfer of food odours to the bait). Traps with even numbers were provided with the odorous foam cubes (changed every two days) and traps with odd numbers were provided with new foam. Trappings were carried out in two series in autumn, the first for 14 days and the second for 10 days. Fifty five bank voles (mean: $2.50 \pm 2.11$ per day) were trapped in traps baited with odour foam and 14 (mean: $0.64 \pm 1.36$ per day) in traps without odour, the latter during the first three days of both trapping series $(p<0.001)$. There was no difference in the number of individuals caught on the first and second day after placing the bait with odour.
\end{abstract}

Institute of Physical Planning and Municipal Economy, Krzywickiego 9, 02-078 Warsaw, Poland (RA); Kampinoski National Park, Krasińskiego 49, 05-080 Izabelin, Poland (EO)

Key words: Clethrionomys glareolus, small mammals, odours, trapping methods

\section{Introduction}

The reaction of small mammals to their conspecific odours is well documented (e.g. Birch 1974, Stoddart 1980). Olfactory signals are especially important for small rodents with limited vision. Due to the fact that their eyes are only a few centimeters above the ground and the vegetation growing in their habitats is generally dense, the horizon for them is most often less than half a meter away. Therefore, chemical signals must play an important role for orientation in the field.

Scent-marking and associated spatial behaviours are well known for house mice Mus musculus (e.g. Carr et al. 1970). Pheromonal signals are used by house mice to condition areas of individual and population activity, enabling swift flight from predators (e.g. Mazdzer et al. 1975), finding the way home (e.g. Bovet 1971, 1972) or finding individuals of the opposite sex (e.g. Ferkin 1990, Holmes 1992).

The basic method used for studying small mammal ecology is live-trapping or snap-trapping with food-bait. Animal reactions to such bait food do not vary considerably so usually a standard bait is used in trappings: textile fragments 
fried in oil and flour or cubes of polyurethane foam soaked with sunflower oil (Grodziński et al. 1966), coconut butter (Nyby et al. 1985), cheese (Andrzejewski et al. 1968, Markov et al. 1968), oat grains (Andrzejewski and Pielowski 1956) and other. The level of attraction to the bait may depend on the available food resources in the environment.

To date, no author studying rodents has solely used odour bait. However, it was pointed out, that traps where animals have already been caught were more readily visited by conspecific individuals than by animals of other species (e.g. Montgomery 1979, Tew 1987, Gurnell and Little 1992). The technique of trapping small mammals with the use of their odours has been tried under laboratory conditions. For example, bedding from cages where animals were kept was used as the bait (e.g. Howard et al. 1977). However, because animals were fed in those cages, it is also possible that the food effected them.

Individual recognition of chemosignals in mammals suggests that this type of bait will work selectively on different categories of animals: individuals of selected species, age, sex, etc. This may be of great importance in both research and application (e.g., in rodent control).

The aim of the study was to determine whether odour bait may be used as an alternative to food in field studies on small rodents.

\section{Study area, methods, material}

The study was carried out in the Kampinos National Park, in an alder-wood (Carici elongatae-Alnetum, Koch 1926), with very dense undergrowth. Trees were estimated to be about 100 years old. A line of 100 snap-traps was set at 2 meter intervals in a forest. A two hundred meter string with sequential numbers of trap-stations was placed in order to keep an equal distance between traps. Traps with odour bait were placed at even number stations and control traps were at odd numbered stations.

In order to obtain the odour bait three male and three female sexually non-active bank voles Clethrionomys glareolus (Schreber, 1780) were trapped in the field and kept in a cage with food and water ad libitum. They were then transferred into a 2 litre glass jar, with a cover allowing for air penetration. Two thirds of the glass was filled with cubes of polyurethane foam $\left(1.5 \mathrm{~cm}^{3}\right)$. The bank voles spent 3 hours in the jar, 3 times daily. While in the jar, the animals were neither fed nor watered. This prevented the transferring of food odours to the bait. Foam cubes were thus soaked with the odour of urine, faeces, and scent glands secretions.

The prepared polyurethane foam cubes were put into snap traps as a bait and were changed every two days. Plastic gloves were used when the bait was installed to eliminate the odour of human hands. Unscented foam cubes were mounted in control traps.

Traps were checked every morning. Species, sex and number of the trap were recorded for every capture. The line of traps was set for 14 days in the first session (19 September - 2 October, 1992) and 10 days in the second (18 October -27 October, 1992). Dry and sunny weather predominated during the first session and cloudy weather with showers and lower average temperature during the second.

A total of 69 bank voles and 5 common shrews Sorex araneus were recorded. All bank voles were sexually non-active. 


\section{Results}

Fifty five of 69 (79.7\%) bank voles were caught in traps with odour bait. Bank voles were caught in control traps only during the first three days of each trapping session. This may be due to interest animals display towards new objects in their environment.

On average, $2.50 \pm 2.11$ bank voles per day were caught in traps with odour bait and $0.64 \pm 1.36$ individuals in the control traps. This difference is significant (pair correlation, $p<0.001$ ).

It was also checked whether the number of bank voles caught during the first day was different from the number of individuals caught during the second. To accomplish this task, the same statistical method was used to compare the numbers of catches in the first and second day after installing the polyurethane foam cubes. On average $3.00 \pm 2.83$ individuals were caught during the first day, and $2.00 \pm 0.89$ during the second. The difference is insignificant $(p<0.4)$. This may indicate that a 48 hour period is too short to observe effects of odour evaporation.

\section{Discussion}

The attractivity of conspecific individual odour was shown in small rodents by several authors (e.g. Idris and Prakash 1986, Ferkin and Seamon 1987, Heske 1987). The influence of odours left in traps on successive trappings of rodents was also analyzed. In most cases the increased attractivity of traps was found where animals had been earlier caught. However, food-bait was used in those experiments so it is difficult to evaluate what degree the increase in trap attractivity resulted from odours left by other animals compared to food odours. Also, when bedding from cages where rodents had been kept and fed was used as a bait (e.g. Rowe 1970, Johnson 1974, Stoddart and Smith 1986) there was a possibility of food odours remaining in the bedding. The method applied in our study prevented the transferring of food odours to traps.

The results of laboratory studies suggest that the odour attractivity for rodents depends on sex, sexual activity and social position (e.g. Carr et al. 1966, Rajska-Jurgiel 1976, Reich and Tamarin 1980, Chitty 1986). It was also shown that olfactory interactions between related species are possible (Drickamer 1984). Our method of obtaining odour bait and testing it may enable us to apply the results towards rodents living in their natural environment.

The results of laboratory studies mentioned above allows for the hypothesis that odour bait may work more selectively on different species or even different categories of individuals than food. The simple method of obtaining odour bait tested in our study may enable us to test this hypothesis. 
The selectivity of odour bait in regards to species, sex and stress factors (e.g. Gurnell 1982, Hurst and Berreen 1986, D'Udine et al. 1987) may be of importance for rodent control in areas where there are both pest species (e.g. in forest plantations) and rare or protected species.

\section{References}

Andrzejewski R., Babińska J. and Gliwicz J. 1968. Results of rodent trapping using cheese and ried wick baiting. Small Mammal. Newslet. 2: 41-43.

Andrzejewski R. and Pielowski Z. 1956. Metoda badań ekologicznych nad drobnymi gryzoniani w warunkach leśnych w oparciu o wykorzystanie przynęty, znakowanie i wypuszczanie złowiorych zwierząt. Ekol. pol. B, 2: 209-214.

Birch M. C. 1974. Feromones. North-Holland Pub. Com., London: 1-461.

Bovet J. 1971. Initial orientation of deer mice (Peromyscus maniculatus) released on snow in honing experiments. Z. Tierpsychol. 28: 211-216.

Bovet J. 1972. Displacement distance and quality of orientation in a homing experiment with ieer mice (Peromyscus maniculatus). Can. J. Zool. 50: 845-853.

Carr W. J., Loeb L. S. and Wylie N. R. 1966. Responses to feminine odors in normal and castrited male rats. J. comp. Physiol. Psychol. 62: 336-338.

Carr W. J., Mortorano R. D. and Crames L. 1970. Responses of mice to odors associated with stess. J. comp. Physiol. Psychol. 71: 223-228.

Chitty D. 1986. Social and local environments of the vole Microtus townsendii. Can. J. Zool. 65: $2555-2566$.

Drickamer L. C. 1984. Captures of two species of Peromyscus at live traps baited with male and female odors. J. Mammal. 65: 699-702.

D’Udine B., Dimitriev Y. and Birke L. I. A. 1987. Patterns of exploration of novel objects in two spejes of murid rodent, Mus musculus L., and Acomys cahirinus (Desmarest). Monitore zool. ital. 21: $77-86$.

Ferkin M. H. 1990. Odor selections of island beach voles during their nonbreeding season. J. Mamnal. 71: $397-401$.

Ferkin M. H. and Seamon J. O. 1987. Odor preference and social behavior in meadow voles, Micrtus pensylvanicus: seasonal differences. Can. J. Zool. 65: 2931-2937.

Grodziński W., Pucek Z. and Ryszkowski L. 1966. Estimation of rodent numbers by means of prebaiting and intensive removal. Acta theriol. 11: 297-314.

Gurnell J. 1982. Trap response in woodland rodents. Acta theriol. 27: 123-137.

Gurnell J. and Little J. 1992. The influence of trap residual odour on catching woodland rodeits. Anim. Behav. 43: 623-632.

Heske E. 1987. Responses of a population of California voles, Microtus californicus, to odor-bated traps. J. Mammal. 68: 64-72.

Holmes D. J. 1992. Sternal odors as cuese for social discrimination by female Virginia opossım, Didelphis virginiana. J. Mammal. 73: 286-291.

Howard W. E., Marsh R. E. and Cole R. E. 1977. Duration of associative memory to toxic bait in deer mice. J. Wildl. Manage. 41: 484-486.

Hurst J. L. and Berreen J. 1986. Observations on the trap-response of wild House mice, Nus domesticus Rutty, in poultry houses. Notes Mammal Soc. 51: 619-622.

Idris M. and Prakash I. 1986. Influence of odours of Indian gerbil, Tatera indica on the social and scent-marking behaviour of asympatric Desert gerbil, Meriones hurrianae. Proc. Indian nant. sci. Acad. B52, 3: 333-340. 
Johnson R. P. 1974. Scent marking with urine in two races of the bank vole (Clethrionomys glareolus). Behaviour 55: 81-93.

Markov G., Christov L. and Gerasimov S. 1968. Rodent trapping with use of differents kinds of bait. Small Mammal. Newslet. 2: 41-43.

Mazdzer E., Capone M. R. and Drickamer L. C. 1975. Conspecific odors and trappability of deer mice (Peromyscus leucopus noveboracensis). J. Mammal. 57: 607-609.

Montgomery W. I. 1979. An examination of interspecific, sexual and individual biases affecting rodent captures in longworth traps. Acta theriol. 24: 35-45.

Nyby J., Kay E., Bean N. J., Dahinden Z. and Kerchner M. 1985. Male mouse (Mus musculus) attraction to airborne urinary odors of conspecifics and to food odors: effects of food deprivation. J. comp. Psychol. 99: 479-490.

Rajska-Jurgiel E. 1976. Interactions between individuals of a population of the bank vole, Clethrionomys glareolus (Schreber, 1780). Ekol. pol. 24: 3-35.

Reich L. M. and Tamarin R. H. 1980. Trap use as an indicator of social behavior in mainland and island voles. Acta theriol. 25: 295-307.

Rowe F. P. 1970. The response of wild house mice (Mus musculus) to live-traps marked by their own and by a foreign mouse odor. J. Zool., Lond. 162: 517-548.

Stoddart D. M. 1980: The ecology of vertebrata olfaction. Chapman and Hall, London and New York: $1-226$.

Stoddart D. M. and Smith P. A. 1986. Recognition of odor-induced bias in the live-trapping of Apodemus sylvaticus. Oikos 46: 194-199.

Tew T. 1987. A comparison of small mammal responses to clean and dirty traps. J. Zool., Lond. 212: 361-364.

Received 14 January 1994, accepted 22 April 1994. 